\title{
Pre-Feasibility Study for Coupling Electronic Waste Recycling With Desert Greening in Africa
}

\author{
Ryunosuke Kikuchi $^{1,2}$, Takaiku Yamamoto ${ }^{3}$ \& Masahi Nakamoto ${ }^{3}$ \\ ${ }^{1}$ Faculty of Science and Technology, Ryukoku University, Otsu, Japan \\ ${ }^{2}$ CERNAS, ESAC - Instituto Politécnico de Coimbra, Coimbra, Portugal \\ ${ }^{3}$ Graduate School of Engineering, Osaka University, Suita, Japan \\ Correspondence: Ryunosuke Kikuchi, Faculty of Science and Technology, Ryukoku University, 1-5 Yokotani, \\ Seta, 520-2194 Otsu, Japan, Tel: 81-77-544-7129. E-mail: kikuchi@risns.ryukoku.ac.jp
}

Received: April 22, 2013 Accepted: September 7, 2013 Online Published: September 26, 2013

doi:10.5539/jsd.v6n10p69 URL: http://dx.doi.org/10.5539/jsd.v6n10p69

\begin{abstract}
Africa suffers from the following serious problems: (i) the distribution of desertification vulnerability suggests that every country is prone to environmental desertification, and desertification processes currently affect about $46 \%$ of the total land area; (ii) the Basel Convention is an international agreement that regulates cross-border shipments of toxic waste, but this tight regulation for prohibiting export of end-of-life electronic devices (so-called e-waste) to the third world has resulted in an increase in illegal transport to Africa. The present research is intended to conduct a technical pre-feasibility study in order to tackle the above-mentioned problems. About $80 \%$ of e-waste comes from television sets and computers, and cathode ray tubes (CRTs) correspond to about $2 / 3$ of the total weight - the neck and funnel parts of CRTs contain toxic materials. The manufacture of foam glasses is considered as safe CRT treatment. The control of soil water is significant to cultivate plants the desert, and the waste-based foam particles can improve water retention in arid soils; i.e. a key proposal is the production of soil amendment from CRT glass. The water-use efficiencies of this amendment's layer are higher than those of the control. Furthermore, leaching fractions of heavy metals from the produced foam glass amendment are lower than the statutory limits.
\end{abstract}

Keywords: Africa, Basel Convention, desertification, e-waste, land degradation

\section{Introduction}

Africa is endowed with enough land to undertake actions to improve household quality, country progress, domestic and international trade, etc. There are, however, some threats and challenges (UNEP, 2008): desertification is considered as a serious problem - about one billion habitants suffer from this desertification, and the situation is growing worse in Sub-Saharan Africa (SSA) in particular.

The word "e-waste" is roughly used to electronic apparatus which is almost or at the end of its life. A global amount of this waste is annually estimated at about 50 million tons (Widmer et al., 2005). The Basel Action Network (2005) reports that the e-waste amount has been growing considerably in developed nations in particular, and some African countries have become dumping grounds for the world's e-waste - e.g. the UNEP (2009) estimates that the South African e-waste amount of end-of-life computers will increase by at least $200 \%$ from 2007 levels in the near future. If action is not taken to appropriately treat materials, such nations have vast amounts of dangerous e-waste with severe environmental problems (UNEP, 2009).

Conducting a pre-feasibility study is one of the key activities within the project initiation phase. As the present paper intends to logically combine two solutions (desertification and e-waste in Africa), it mainly aims to justify this combination in terms of technical feasibility. Basic information about desertification and e-waste is reviewed first, followed by a description of the principal discussion.

\section{Desertification}

Based on data published by Reich et al. (2001), desertification means that soil in arid, semi-arid, and dry sub-humid lands is degraded by some aspects such as climatic change and anthropogenic causes. A desertification phenomenon damages about $\sim 46 \%$ in African land. 


\subsection{Drivers of Land Degradation}

Land degradation reduces or destroys soil productivity, vegetation, arable and grazing land, as well as forest. In the most extreme cases, hunger and poverty set in and become both the cause and consequence of further degradation (UNCCD, 2011). Drivers of land degradation can be classified as (review in Mainguest, 2001): (i) natural, which means climatic change, reduction in rainfall, and increase in the frequency of drought, but also excessive rainfalls with destructive floods; and (ii) anthropogenic, which includes socioeconomic aspects with unavoidable feedback that desertify land by reducing its productive potential, leading to much more demand and further destruction of land.

High, sustained temperatures lasting for months with infrequent and irregular rainfall lead to drought and difficult growing conditions for plants and trees. As a result, severe hydrological imbalances jeopardize natural production systems (UNCCD, 2011). In countries where major economic resources are dependent on agricultural activities, there are few alternative sources of income, or none at all. Soil is damaged by excessive use when farmers neglect or shorten fallow periods, which are necessary to allow the soil to recover sufficiently to produce enough food to feed the population.

\subsection{Countering Desertification}

The desertification factors are associated with soil acidity, non-permeable soil layers, water logging, tendency to keep salts or some attributes (see Table 1). It is considered that the soil quality is an original land property or due to human-caused degradation in Africa (Oldeman et al., 1991).

Conventional techniques have been experimented in terms of diminishing the desert area and recover the degraded land, but the applied measures mainly deal with sand movement (cf. Sugiyama, 1984). It is now known that there are some techniques to manage and combat desertification - landscaping modification to reduce evaporation and erosion, regeneration of salty or degenerated soils, flood control, prevention of overgrazing and firewood use, etc.

Desert greening is usually related with a water utility. If enough water for irrigation is available, any desert can be basically greened. However, the water issue is put on a wide range of subjects such as impeded drainage, seasonal moisture stress, etc. In this paper, attention is mainly focused on the water-holding capacity of soils. The soils with low water-holding capacity occupy about $20 \%\left(5.3\right.$ million $\left.\mathrm{km}^{2}\right)$ of the land area in Africa, and this rate is recognized as the inherent quality of African land (see Table 1).

Table 1.Typical land stresses and inherent land quality in Africa (after Reich et al., 2001).

\begin{tabular}{cccc}
\hline \multicolumn{2}{c}{ Land stress } & \multicolumn{2}{c}{ Inherent quality of land } \\
\hline Stress type & Area $\left(1,000 \mathrm{~km}^{2}\right)$ & Area $\left(1,000 \mathrm{~km}^{2}\right)$ & Land occupation (\%) \\
\hline High soil temperature & 910 & 1319 & 4.5 \\
Impeded drainage & 520 & 898 & 3.1 \\
Nutrient leaching & 110 & 5932 & 20.2 \\
Low water holding & 2219 & 5309 & 18.1 \\
Shallow soil & 1016 & 1394 & 4.8 \\
Moisture stress & 13551 & 13551 & 46.2 \\
\hline
\end{tabular}

\section{Electronic Waste}

The disposal amount of electronic devices, such as personal computers (PCs), mobile phones and so on is globally increasing (Widmer et al., 2005). It is reported that old-fashioned PCs increased from $\sim 20$ million in 1994 to $\sim 100$ million in 2004 (Widmer et al., 2005). The cumulative amount of disposal PCs corresponds to 2,873,000 tons plastics, 719,000 tons Pb, 1,364 tons Cd and 287 tons Hg (Puckett \& Smith, 2002). This disposal tendency indicates that the $\mathrm{PC}$ business is not saturated and its life span is considerably diminishing: i.e. from 5 years in 1997 to 2 years in 2005 (Culver, 2013).

\subsection{Transboundary Trade and Basel Convention}

The transboundary movement of electronic waste is restricted by the Basel Convention because such waste it is considered to be dangerous according List A of Annex VIII of the Convention. It is hard to answer to a question 
of who exports e-waste to Africa - end-of-life devices are exported through illegal network by brokers in an unreground market (Schmidt, 2006). An example in Nigeria is reported in BBC News (Carney, 2006) as follows: in custom documents, electronic equipment at the end of its useful life is described as being "shipped for re-use". This category of re-use category raises their profits and reduces their responsibilities for environment and safety. The brokers intentionally mix bad devices (i.e. useless junk) with good ones so that they can evade disposal and/or recycling costs. This trade results in huge waste piles in the countryside (Schmidt, 2006; also see Figure $1)$.
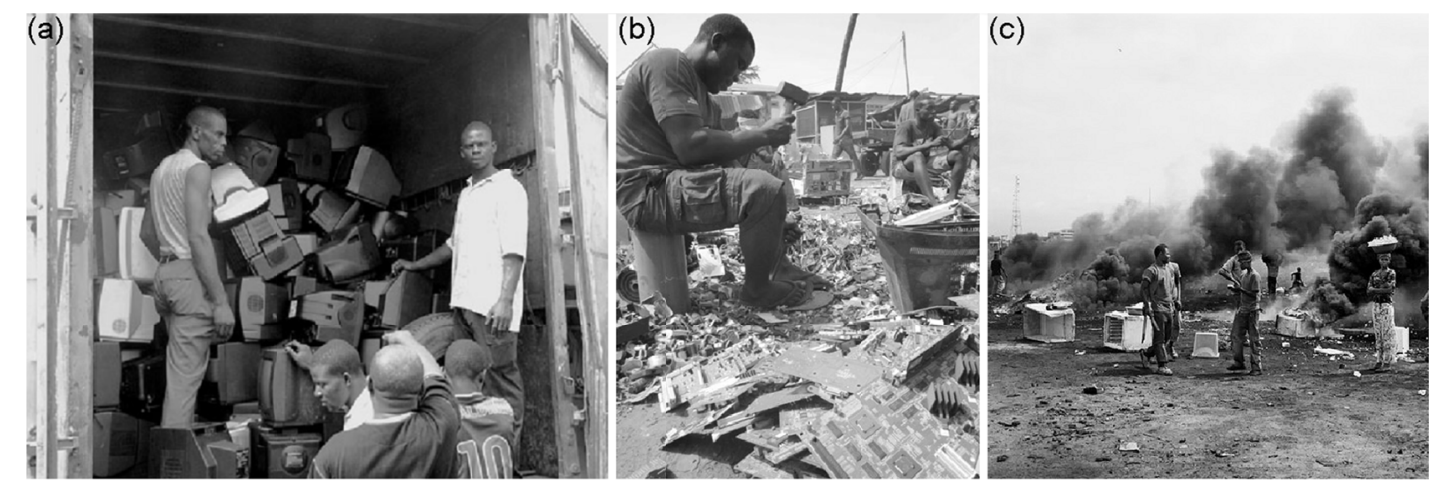

Figure 1. Dumping e-waste in African regions (courtesy Basel Action Network, Treehugger and P. Hugo): (a) workers at e-waste dumping site (Alaba) in Nigeria, (b) sorting e-waste in Ghana, and (c) e-waste burning in

South Africa

\subsection{Current Situation of E-Waste in Africa}

Some examples are given: (i) though there are not e-waste recycling facilities in Nigeria, 15,000-45,000 tons of PCs are annually imported to Nigeria and these PCs are not usable/repairable. (Nnorom \& Osibanjo, 2008); (ii) material fractions of e-waste (plastics, $\mathrm{Fe}$ and $\mathrm{Al}$ ) are melted and used in the production of agricultural equipment in Kenya, but there are not proper recycling facilities for the other fractions such as $\mathrm{Cu}$, circuit boards, cathode ray tubes (CRTs) and other hazardous metals (Pb, Hg, Li, etc.) (Mureithi \& Waema 2008); and (iii) in Uganda, about $15 \%$ of the imported computers are classified as second-hand in Uganda (Schluep \& Wasswa, 2008).

\subsection{Composition of E-Waste}

From the viewpoint of components (review in Andreola et al., 2005), about $80 \%$ of e-waste comes from television sets (TVs) and computers. Due to rapid advances in video screen technology, innovative appliances such as Liquid Crystal Displays (LCDs) and Plasma Display Panels (PDPs) have superseded conventional TVs. The 2006 statistic data indicate that 163,420 TVs and computers became obsolete every day in the USA (Yang \& Williams, 2009). Cathode ray tubes (CRTs) correspond some two-thirds of the monitor weight, and they consist of ca $85 \%$ glass and $15 \%$ plastic and metal (Andreola et al., 2007). For this kind of waste, the European amount of CRT waste is annually 300,000 tons (CEC, 2000). From a global perspective (review in Xu et al., 2012), only $26 \%$ CRT waste gets recycled, $59 \%$ is disposed of in landfills and $15 \%$ are incinerated. CRTs are composed of diverse glass components: previous toxicity studies of CRT glass demonstrate that the neck and funnel parts are harmful, but the panel part shows low levels of toxicity (Jang \& Townsend, 2003; Musson et al., 2000).

The CRT recycle seems not to be economical because the recycled glass has little options for its application (BAN, 2004). Thus, great amounts of CRT-containing appliances are transported to developing nations under the pretext of "reuse and bridging the digital divide" (Nnorom et al., 2011). Recycling infrastructure is not well equipped to deal with electronic wastes in most developing nations, so end-of-life CRTs are dumped with municipal waste in vacant plots (Nnorom et al., 2011). There is a strong possibility that unsanitary disposal of waste CRTs may cause extensive pollution with heavy metals, particularly Pb (Nnorom et al., 2011).

\section{Technical Feasibility for Combining E-Waste With Desert Greening}

As stated in section 2, water availability is an important factor in desert greening, and the soils with low capacity for water retention occupy about $20 \%$ of the land area in Africa. As mentioned in section 3, a great amount of electronic waste is currently sent to African nations, but most of these nations do not have proper infrastructure, 
policy or legislation in e-waste treatment. Since CRT glass occupies a great portion of e-waste (cf. section 3.3), it is discussed whether the application of CRT glass to improving the water-holding capacity of soil is technically feasible. Figure 2 illustrates a schematic of the CRT components. The procedures for recycling end-of-life CRT glass are problematic because of the different components.

\subsection{Recycling of CRT Glass}

There are mainly two processes for recycling of CRT glass (Siikamaki, 2003). In closed-loop process, disposal CRTs are reused for manufacture of new CRT glass; however, this recycling is subject to market limitation because the CRT television has been rapidly replaced by new products: LCDs and PDPs (cf. section 3.3). In open-loop process, the glass is reused for the following alternative applications (ICER, 2004): bricks, tiles, flux in brick, flux in ceramic ware, foam glass, and fluxing material in metal smelting.

A European research project by the Industry Council for Electronic Equipment Recycling (2004) assesses the above-mentioned applications as follows: (i) application to bricks and tiles is suitable only for unleaded panel glass; (ii) use of CRT as flux is also suitable for unleaded panel part; (iii) with regard to foam glass, there are less obstacles to applying disposal CRT glass and no environmental effects in comparison to applying other kinds of waste glass; and (iv) smelting operations of CRT glass need to recover the contained lead and make the obtained slag non-toxic.

Therefore, the production of foam glasses from CRT glass can be considered as a promising process for recycling of waste CRTs.

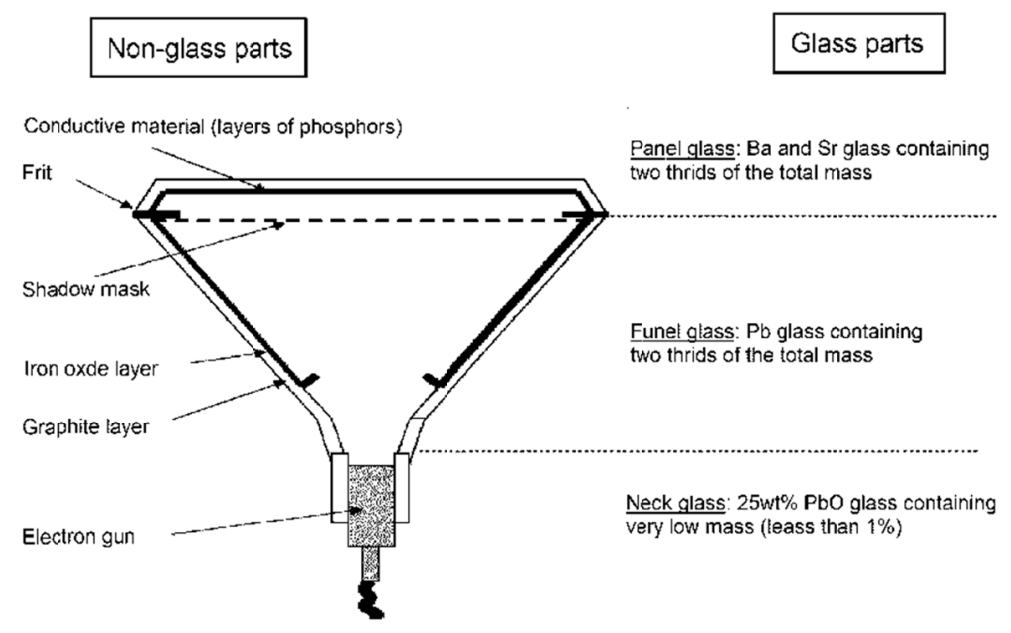

Figure 2. Schematic of the CRT components (redrawn from Keller, 1992; Mear et al., 2006a)

\subsection{Production of Foam Glass From Waste CRT}

Foam glass has been commercialized since the 1930s (ICER, 2004). There are presently many foam glass factories that use a great portion (ca 98\% at the maximum) of waste glass (ICER, 2004). A gas is generated in glass at $700-900{ }^{\circ} \mathrm{C}$, and this gas forms foam glass (ICER, 2004). The gas expansion produces a cell structure with high porosity. The raw material in foam glass production is either a molten glass or sintered glass particles. The latter uses ground glass (below $100 \mu \mathrm{m}$ ) with a foaming agent. Upon being heated, this agent liberates a gas that can expand the mass of molten particles (ICER, 2004).

It is proposed to add $\mathrm{SiC}$ and $\mathrm{TiN}$ in order to foam waste glasses. These compounds act as reducing agents and generate gases such as $\mathrm{CO}_{2}$ and $\mathrm{N}_{2}$ at $800-900{ }^{\circ} \mathrm{C}$. This gas formation facilitates to smoothly foam a softened glass phase (Mear et al., 2006b). A systematic study of the process parameters (Cambon \& Liautard, 2006) shows the possibility of modifying the properties of the obtained foam glass: (i) the density can vary from 0.4 to $0.8 \mathrm{~g} \mathrm{~cm}^{-3}$; (ii) the mechanical stress with a uniaxial compressive loading from 20 to $60 \mathrm{MPa}$; (iii) thermal conductivity $\mathrm{K}$ inferior to $0.25 \mathrm{Wm}^{-1} \mathrm{~K}^{-1}$ and dielectric constant $\varepsilon$ r between 2.1 and 3.1 at $25{ }^{\circ} \mathrm{C}$; (iv) they are non-combustible (like bulk glass) and resist corrosion in any environment; and (v) they present a low thermal expansion coefficient. The porosity varies from 67 to $86 \%$, and its value depends on the reaction processes such as temperature and time effects (Cambon \& Liautard, 2006). 


\subsection{Application of Foam Glass to Soil Amendment}

Foam particles generally absorb water, and this absorption has a high capacity of water retention in (Andersen, 2013). Thus, there a possibility that the foam particles reduce the amount of water demand in irrigation. Furthermore, the foam particles discharge water to the plant roots as the surrounding soil moisture drops (cf. Hara et al., 2003). Heated to the softening temperature, this inorganic material will not be decomposed soil microbes, but it will act as a substrate for them (Ramsey \& Ungerleider, 2007). Inorganic amendments such as porous material offer some benefits for improving sand-based root zones (Habeck \& Christians, 2000); that is, they are less prone to compaction than organic materials and have higher cation exchange and water holding capacities without reducing non-capillary pore space (air-filled porosity). They are essentially permanent additions to the root zones, demonstrating very little break down over time (Habeck \& Christians, 2000).

\subsection{Field Test of Amendment Produced From Waste Glass}

As stated in section 4.3, foam glass can be prepared from end-of-life glass through reaction with a reducing agent at a high temperature. The waste-based foam glass for soil amending has been commercialized - Porous $\alpha$, Nextone $\alpha$ and so on (cf. Yamane \& Takeuchi, 2009). A field test using such foam glass is presented according to published data (Ahmed \& Inoue, 2009). The tested soil contains $95 \mathrm{wt} \%$ sand, $1.2 \mathrm{wt} \%$ silt and $3.8 \mathrm{wt} \%$ clay. This soil shows water holding capacity of $0.06 \mathrm{~cm}^{3} \mathrm{~cm}^{-3}$, wilting point of $0.028 \mathrm{~cm}^{3} \mathrm{~cm}^{-3}$ and field capacity of $0.09 \mathrm{~cm}^{3} \mathrm{~cm}^{-3}$. The characteristics of the materials applied in this field test can be seen from Table 2 .

Table 2. Characteristics of the materials applied in the field test (after Ahmed \& Inoue, 2009).

\begin{tabular}{|c|c|c|}
\hline \multirow{2}{*}{ Parameter } & \multicolumn{2}{|r|}{ Value } \\
\hline & Soil & Waste-based vitreous amendment \\
\hline Electrical conductivity, $\mathrm{dS} \mathrm{m}^{-1}$ & 0.012 & 8.36 \\
\hline $\mathrm{pH}$ & 6.7 & 10.3 \\
\hline Exchangeable $\mathrm{K}^{+}$, cmol kg ${ }^{-1}$ & 3.3 & 3.24 \\
\hline Exchangeable $\mathrm{Ca}^{2+}, \mathrm{cmol} \mathrm{kg}^{-1}$ & 3.4 & 31.7 \\
\hline Exchangeable $\mathrm{Mg}^{2+}, \mathrm{cmol} \mathrm{kg}^{-1}$ & 0.17 & 0.37 \\
\hline Exchangeable $\mathrm{Na}^{+}, \mathrm{cmol} \mathrm{kg}^{-1}$ & 0.14 & 0.15 \\
\hline Cation exchange capacity, $\mathrm{cmol} \mathrm{kg}^{-1}$ & 0.40 & 2.51 \\
\hline Bulk density, $\mathrm{g} \mathrm{cm}^{-3}$ & 1.57 & 1.1 to 1.3 \\
\hline Hydraulic conductivity, $\mathrm{cm} \mathrm{s}^{-1}$ & 0.052 & 0.002 \\
\hline
\end{tabular}

The test field consists of two amendment layers of $2 \mathrm{~cm}$ and $5 \mathrm{~cm}$ thickness in the soil and one control without amendment. Swiss chard was sown in this field in April, and a compound NPK fertilizer 8-8-8 was applied each 10 days. A drip system was used to irrigate this filed: $40 \mathrm{~cm}$ of emitter distance and $2 \ell \mathrm{h}^{-1}$ of discharge rate with $0.1 \mathrm{MPa}$. Water irrigation started 14 days after seeding, and it continued until the harvest time in July.

The term of water use efficiency means a level of fresh yield per unit of water used up in the crop growth, and this efficiency is often considered an important determinant of yield under stress and even as a component of crop resistance (Stiles \& Cocking, 1969). The efficiencies obtained from the field test are summarized in Table 3.

Table 3. Irrigation, crop yield and water-use efficiency in the test field (after Ahmed \& Inoue, 2009).

\begin{tabular}{lccc}
\hline & $\begin{array}{c}\text { Water input, } \\
\mathrm{mm}\end{array}$ & $\begin{array}{c}\text { Yield, ton } \mathrm{ha}^{-1} \text { on a } \\
\text { fresh weight basis }\end{array}$ & $\begin{array}{c}\text { Water-use efficiency, }^{-1} \\
\text { on a fresh weight basis }\end{array}$ \\
\hline Control & 440 & 4.15 & 1.07 \\
Amendment layer of $2 \mathrm{~cm}$ & 369 & 12.09 & 4.91 \\
Amendment layer of $5 \mathrm{~cm}$ & 369 & 11.05 & 4.49 \\
\hline
\end{tabular}


It follows from Table 3 that the water-use efficiencies of the amendment layer are higher than those of the control. The desert generally shows a low holding capacity of water, so it can be considered that plant growth is poor due to a low content of soil water (Ahmed \& Inoue, 2009). As compared to the control, the obtained results indicate that the addition of vitreous amendment can improve water holding capacity required for biological growth.

A demonstration test has already started to prove the application of waste-based foam glass to desertification greening in the Sahara desert of Mauritania (Figure 3).

(a)

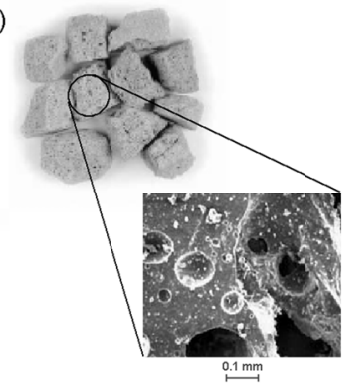

(b)

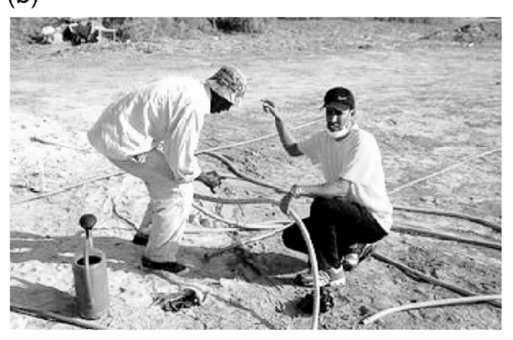

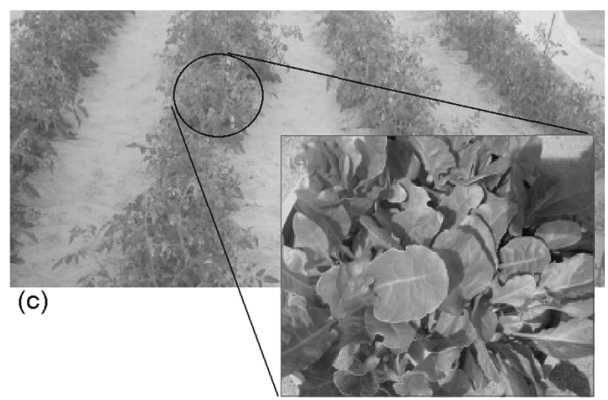

Figure 3. Demonstration test for application of waste-based foam glass to crop cultivation in the Sahara desert of Mauritania (courtesy Tottori Resource Recycling): (a) grains of waste-based foam glass (size of $\sim 1.0 \mathrm{~mm}$ ) and microscope image of its porosity; (b) preparation of test field, and (c) tomato cultivation (2-cm layer of foam glass amendment).

\section{Consideration From the Environmental Viewpoint}

There is considerable evidence published in professional scientific journals demonstrating that lead cause negatively impacts on the environment (review in NRC, 1980). As stated in section 3.1, e-waste is considered to be hazardous, and its international movement is restricted by the Basel Convention because. CRT glass in particular contains a great amount of lead (cf. section 4.1). The lead contained in CRT glass seems to be an emerging issue facing environment management; hence, CRT-associated lead is discussed below.

\subsection{Lead Leachability From Disposal CRT}

Using the toxicity leaching procedure by the US EPA, lead leachability from 36 samples of CRT is reported as follows (Musson et al., 2000): the leaching concentration was $22.1 \mathrm{mg} \ell^{-1} \mathrm{~Pb}$ on average in 21 of 30 color CRTs, i.e. this value exceeded the permissible limit of $5.0 \mathrm{mg} \ell^{-1}$. For color CRT samples, the $\mathrm{Pb}$ leachability ranged

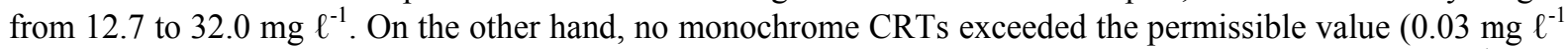
on average). As to monochrome CRTs, the $99 \%$ confidence interval was between 0.02 to $0.05 \mathrm{mg}^{-1}$. The greatest amount (75.3 $\mathrm{mg}^{-1}$ on average) of Pb leaching was recorded in the CRT funnel part.

\subsection{Metal Leachability From CRT-Based Foam Glass}

Manufacture of foam glass is considered to be environmentally friendly solution to CRT glass treatment and desert greening, but CRTs contain heavy metals; hence, it is important to clarify the leaching mechanism of foam glasses produced from CRTs. The metal fixation in CRT-based foam is assessed according to the AFNOR X 31-210 procedure equivalent to EN 12457/4 test (Yot \& Mear, 2011): (i) the amount of metal leached foam glass is affected by on the original property and the addition of a reducing agent ( $\mathrm{SiC}, \mathrm{TiN}$ etc.); (ii) the $\mathrm{Pb}$ amount leached from CRT-based foam glass is not greater than that leached from funnel glass; and (iii) leachate levels of $\mathrm{Ba}$ and $\mathrm{Sr}$ are similar in diverse tests, and they are also less than regulatory limits. It is proved that $\mathrm{Pb}$ reduction randomly takes place in the sample and forms g to macroscopic droplets (Pascal \& Mear, 2011). In any case, the above-mentioned behavior implies that the CRT-based foam glass can properly fix the metals originally contained.

\subsection{Lead Separation from End-of-Life CRT Glass}

Doubts remains as to whether it is technically possible to clean waste CRT glass. For this treatment, some methods have been proposed: e.g. self-propagation process (Chen et al., 2009a), pyrovacuum process (Chen et al., 2009b), etc. As there is a possibility that phase separation in the melt system may remove lead from CRT glass at a high efficiency, we conducted a preliminary experiment of our proposed reduction melting with iron as 
reducing agent to evaluate the technical feasibility (Nakamoto \& Yamamoto, 2010): a sample of CRT glass containing $19.1 \mathrm{wt} \% \mathrm{PbO}$ was mixed with $\mathrm{CaO}$ as the auxiliary agent, and this mixture was melted and reduced to $\mathrm{Pb}$ in an iron crucible at $1,350{ }^{\circ} \mathrm{C}$. The $\mathrm{PbO}$ content of $0.4 \mathrm{wt} \%$ was measured in the glass phase; to put it differently, the $\mathrm{PbO}$ contained in $\mathrm{CRT}$ glass can be recovered as metallic lead at a high efficiency. However, this recovery should be more technically sophisticated, and a pilot-scale test is also required to assess its feasibility and cost performance on an industrial scale.

\section{Conclusions}

Although the Basel Convention regulates cross-border shipments of toxic waste (cf. section 3.1), it is reported that embargoing e-waste trade to third nations is an idealistic attempt resulting in illegal transport (review in Mueller et al., 2012). In any case, it is important to obey this convention protecting human health and the environment from toxic waste. One problem remains in how to solve the vast amount of e-waste already exported and accumulated. The other problem is the desertification that currently affects African land in particular (section 2). The study presented in this paper aimed at discussing the combination of e-waste management with desert greening in Africa, and this combination is concluded to be feasible.

\section{Acknowledgements}

The DESIRE project intends to promote land use and management conservation strategies in degradation and desertification spots around the world. Since one of the authors of the present manuscript is a collaborator researcher of the CERNAS - ESAC/IPC (a partner with this project) and has been discussing environmental management with the academic staff of Agostinho Net University of the Republic of Angola (a country in south-central Africa), such background brought attention to counter-desertification and the waste issue. Thanks are due to Professor A. D. Ferreira of CERNAS for suggesting desertification issues, to Mr. R. Kitamura of Ryukoku University for laboratorial work, and to Mrs. C. Lentfer for English check.

\section{References}

Ahmed, B. A. O., \& Inoue, M. (2009). Increasing crop productivity using a porous amendment in sandy soil. Journal of Food, Agriculture \& Environment, 7(2), 546-550.

Andersen, C. (2013). Waste glass based soil amendment retains moisture. Retrieved from http://contest.techbriefs.com/component/content/article/618

Andreola, F., Barbieri, L., Corradi, A., Ferrari, A. M., Lancellotti I., \& Neri, P. (2007). Recycling of EOL CRT glass into ceramic glaze formulations and its environmental impact by LCA approach. International Journal of Life Cycle Assessment, 12, 448-454.

Andreola, F., Barbieri, L., Corradi, A., Lancellotti, I., Falcone, R., \& Hreglich, S. (2005). Glass-ceramics obtained by the recycling of end of life cathode ray tubes glasses. Waste Management, 25, 183-189. http://dx.doi.org/10.1016/j.wasman.2004.12.007

Barnes, D. F. (1990). Population growth, wood fuels, and resource problems in sub-Saharan Africa (Industry and Energy Department Working Paper No. 26). Washington, DC: World Bank.

Basel Action Network - BAN. (2004). CRT Glass Recycling Survey Results. Seattle: BAN Earth Economics.

Basel Action Network - BAN. (2005). The digital dump - exporting re-use and abuse to Africa (No. FH11). Seattle: BAN Earth Economics.

Cambon, M., \& Liautard, B. (2006). Development of a way to recycle waste glasses: preparation of porous materials from cathode-ray-tubes and/or packaging glasses at the end of their life time. In: V. Popov, A. G. Kungolos, C. A. Brebbia \& H. Itho (Eds.), Waste Management and the Environment III (pp. 287-294). Southampton: Wessex Institute of Technology.

Carney, L. (2006, December 19). Nigeria fears e-waste "toxic legacy". BBC News.

Chen, M., Zhang, F. S., \& Zhu, J. (2009a). Detoxification of cathode ray tube glass by self-propagation process. Journal of Hazardous Materials, 165(1/3), 980-986. http://dx.doi.org/10.1016/j.jhazmat.2008.10.098

Chen, M., Zhang, F. S., \& Zhu, J. (2009b). Lead recovery and the feasibility of foam glass production from funnel glass of dismantled cathode ray tube through pyovacuum process. Journal of Hazardous Materials, 161(2/3), 1109-1113. http://dx.doi.org/10.1016/j.jhazmat.2008.04.084

Commission of the European Communities - CEC. (2000). Proposal for a Directive of the European Parliament and of the Council on waste electrical and electronic equipment (COM 2000/347). Brussels: CEC. 
Culver, J. (2013). The life cycle of a CPU. Retrieved from http:// www.cpushack.net/life-cycle-of-cpu.html

Habeck, J., \& Christians, N. (2000). Time alters greens key characteristics. Golf Course Management, 68(5), 54-60.

Hara, Y., Hara, M., Momozaki, S., \& Yasuda, I. (2003). Bedrock vegetation system using wastes - the case study using thined-wood and Foamed Waste Glass. In: Conference proceedings of the Japanese society of Irrigation drainage and rural engineering (JSIDRE) (pp. 638-639). Tokyo: JSIDRE (in Japanese).

Industry Council for Electronic Equipment Recycling - ICER. (2004). Materials recovery from waste cathode ray tubes (No. GLA15-006). Oxon: Waste \& Resources Action Programme.

Jang, Y. C., \& Townsend, T. G. (2003). Leaching of lead from computer printed wire boards and cathode ray tubes by municipal solid waste landfill leachates. Environmental Science and Technology, 37, 4778-4784. http://dx.doi.org/10.1021/es034155t

Keller, P. A. (1992). The cathode-ray tube - technology, history and applications. Jamestown: Palisades Press.

Mainguest, M. M. (2001). Desertification. In: D. E. Alexander, \& R. W. Fairbridge (Eds.), Encyclopaedia of Environmental Science (pp. 125-129). Dordrecht: Kluwer Academic.

Mear, F., Yot, P., Cambon, M., \& Ribes, M. (2006a). The characterization of waste cathode-ray tube glass. Waste Management, 26, 1468-1476. http://dx.doi.org/10.1016/j.wasman.2005.11.017

Mear, F., Yot, P., \& Ribes, M. (2006b). Effects of temperature, reaction time and reducing agent content on the synthesis of macroporous foam glasses from waste funnel glasses. Material Letter, 60, 929-934. http://dx.doi.org/10.1016/j.matlet.2005.10.046

Mueller, J. R., Boehm, M. W., \& Drummond, C. (2012). Direction of CRT waste glass processing - electronics recycling industry communication. Waste Management, 32, 1560-1565. http://dx.doi.org/10.1016/j.wasman.2012.03.004

Mureithi, M., \& Waema, T. (2008). E-waste Management in Kenya. Nairobi: Kenya ICT Action Network (KICTANet).

Musson, S. E., Jang, Y. C., Townsend, T. G., \& Chung, I. H. (2000). Characterization of lead leachability from cathode ray tubes using the toxicity characteristic leaching procedure. Environmental Science and Technology, 34, 4376-4381. http://dx.doi.org/10.1021/es0009020

Nakamoto, M., \& Yamamoto, T. (2010). Separation of Pb from Pb glass by Smelting Reduction using Fe. Journal of the Japanese Society for Experimental Mechanics, 10(3), 301-303.

National Research Council. (1980). Lead in the human environment (No. PB-82-117136). Washington, DC: National Academy of Sciences..

Nnorom, I. C., \& Osibanjo, O. (2008). Electronic waste (e-waste): material flows and management practices in Nigeria. Waste Management, 28(8), 1472-1479. http://dx.doi.org/10.1016/j.wasman.2007.06.012

Nnorom, I. C., Osibanjo, O., \& Ogwuegbu, M. O. C. (2011). Global disposal strategies for waste cathode ray tubes. Resources, Conservation and Recycling, 55(3), 275-290. http://dx.doi.org/10.1016/j.resconrec.2010.10.007

Oldeman, L. R., Hakkeling, R. T. A., \& Sombroek, W. G. (1991). World Map of the Status of Human-Induced Soil Degradation (an explanatory note). Wageningen: International Soil Reference and Information Centre.

Puckett. J., \& Smith, T. (2002). Exporting harm: the high-tech trashing of Asia. Seattle: The Basel Action Network..

Ramsey, W. G., \& Ungerleider, A. (2007). Foamed vitroeous materials for agricultural application. U.S. Patent Application Publication, US018467, A1.

Schluep, M., \& Wasswa, J. (2008). e-Waste assessment in Uganda - a situational analysis of e-waste management and generation with special emphasis on personal computers. Kampala: Uganda Cleaner Production Center.

Schmidt, C. W. (2006). Unfair trade - e-waste in Africa. Environmental Health Perspectives, 14(4), 233-235.

Siikamaki, L. A. R. (2003). End-of-life cathode ray tube glass as a raw material for hollow ware glass products. In R. K. Dhir, M. D. Newlands \& J. E. Halliday (Eds.), Recycling and reuse of waste materials (pp. 743-750). London: Thomas Telford.

Stiles, W., \& Cocking, E. C. (1969). An introduction to the principles of plant physiology. London: Methuen.

Sugiyama, R. (1984). Trial to desert greening. Fukuoka: Asishoho (in Japanese). 
United Nations Convention to Combat Desertification - UNCCD. (2011). Desertification - a visual synthesis. Bonne: UNCCD Secretariat.

United Nations Environment Program - UNEP. (2008). Land degradation and desertification in Africa. Washington, DC: Environmental Information Coalition.

United Nations Environment Program - UNEP. (2009). Sustainable Innovation and Technology transfer Industrial Sector Studies "RECYCLING FROM E-WASTE TO RESOURCES” (No. DTI/1192/PA). Paris: UNEP Division of Technology, Industry and Economics.

Widmer, R., Oswald-Krapf, H., Sinha-Khetriwal, D., Schnellmann, M., \& Boni, H. (2005). Global perspectives on e-waste. Environmental Impact Assessment Review, 25(5), 436-458. http://dx.doi.org/10.1016/j.eiar.2005.04.001

Xu, O., Li, G., He, W., Huang, J., \& Shi, X. (2012). Cathode ray tube (CRT) recycling: Current capabilities in China and research progress. Waste Management, 32, 1566-1574. http://dx.doi.org/10.1016/j.wasman.2012.03.009

Yamane, T., \& Takeuchi, Y. (2009). Development of soil conditioner "Porous $\alpha$ ". In: Industry Department of METI Chugoku (Ed.), Real Work Style - Selection 2009 (pp. 10-11). Horoshima: METI Chugoku Bureau.

Yang, Y., \& Williams, E. (2009). Logistic model-based forecast of sales and generation of obsolete computers in the US. Technological Forecasting and Social Change, 76, 1105-1114. http://dx.doi.org/10.1016/j.techfore.2009.03.004

Yot, P. G., \& Mear, F. O. (2009). Lead extraction from waste funnel CRT glasses by reaction with silicon carbide and titanium nitride. Journal of Hazardous Materials, 172(1), 117-123. http://dx.doi.org/10.1016/j.jhazmat.2009.06.137

Yot, P. G., \& Mear, F. O. (2011). Characterization of lead, barium and strontium leachability from foam glasses elaborated using waste cathode ray-tube glasses. Journal of Hazardous Materials, 185(1), 236-241. http://dx.doi.org/10.1016/j.jhazmat.2010.09.023

\section{Copyrights}

Copyright for this article is retained by the author(s), with first publication rights granted to the journal.

This is an open-access article distributed under the terms and conditions of the Creative Commons Attribution license (http://creativecommons.org/licenses/by/3.0/). 